\title{
Russian-Chinese Relations in the Field of Culture (1990-s - 2000-s)
}

\author{
Ramil M. Valeev ${ }^{1} \&$ Alfiya R. Alikberova ${ }^{1}$ \\ ${ }^{1}$ Kazan (Volga Region) Federal University, Kazan, Russia \\ Correspondence: Alfiya R. Alikberova, Kazan (Volga Region) Federal University, Kremlyovskaya street, 18, \\ Kazan 420008, Russia. E-mail: alfiakasimova@gmail.com
}

\author{
Received: April 14, 2015 Accepted: April 20, 2015 Online Published: April 27, 2015 \\ doi:10.5539/jsd.v8n4p132 URL: http://dx.doi.org/10.5539/jsd.v8n4p132
}

\begin{abstract}
The relevance of the study of this problem stems from the fact that the Russian-Chinese relations are one of the most important indicators of the situation in the world. They are the source of dependence not only for political, socio-economic situation in the Asia-Pacific Region (APR), but also the global political climate. In recent years, it has become more and more obvious and urgent to formulate new theoretical and practical approaches to the study of interaction between Russia and China, which both have bright cultural and historical features. Humanitarian ties play a great role in the relationships between these states and have a major impact on the process of their interaction. The article provides an overview of Russian-Chinese relations in the field of culture in the 1990s - 2000s. Particular attention is paid to the coverage of cooperation of intergovernmental organizations of Russia and China in the field of culture and education, as well as reviews the regulatory framework of the cultural partnership between Russia and China. The aim of the present work is a detailed analysis and evaluation of key bilateral humanitarian projects during the study period. The article submissions may be useful for specialists involved in the study of Russian-Chinese relations at the present stage, researchers and university teachers of the humanities. The article is also recommended to undergraduate, graduate and post-graduate students with in-depth research training.
\end{abstract}

Keywords: Russian-Chinese relations, regional policy, humanitarian projects, legal framework of the Russian-Chinese relations, cultural ties, Russian-Chinese relations in the field of culture

\section{Introduction}

Cooperation in the field of culture and education is the foundation for the development of modern Russian-Chinese relations. Normalization of political relations between the two countries in the late 1980s early 1990s was the prerequisite for the development of humanitarian ties of a new level (Grishin, 2010). The aim of the present study is the analysis of complex steps, branches and main results of the development of cultural and educational relations between the Russian Federation and the People's Republic of China in the 1990s - 2000s.

Intergovernmental agreement on cultural cooperation from 18.12.1992, the (Collection of Russian-Chinese Conventions, 1999), intergovernmental Plans cultural cooperation, as well as the Program of Cooperation between the Ministries of Culture of the Russian Federation and the People's Republic of China have become the main modern legal framework basis for the development of interstate cultural ties (Official site of the RF Ministry of Education, 2014).

Interstate, regional and departmental levels of cultural cooperation between the two countries were formed and developed in 1990-2000-es. Interstate level was closely associated with the main trends, problems of international relations and the intensification of political, economic and trade ties between Russia and China.

Regional Russian-Chinese ties have developed at the level of administrative-territorial initiations of the two countries (Bazarov, Ganzhur, 2002). In the mid-90s of the XXc. more than fifty territories, regions and cities of Russia were involved into the cooperation with China at the regional level. The main events of interregional relations between Russia and China developed along the length of the Russian-Chinese border and took the form of cross-border cooperation. An important outcome of the bilateral relations at this level was the formation of twinned towns and districts. Cultural and sport exchange took place in these regions (Larin, 2005).

Scientific novelty of the research is as follows: it is for the first time since 1992 when a comprehensive study of Russian-Chinese relations in the field of culture and education has been conducted : systematic and 
comprehensive study of the stages, trends and characteristics of modern cultural and educational relations between Russia and China has been implemented; a comprehensive analysis of the development of Russian-Chinese relations in the sphere of culture and education, on the basis of interstate legal framework has been carried out; the major humanitarian projects in Russia and China have been highlighted, the role, scale and dynamics of Russian-Chinese relations in the field of culture and education have been evaluated.

\section{Methodological Framework}

The principles of historicism and scientific objectivity, systemic, the description and analysis of specific situations, international projects, their explanation, comparison and generalization are the methodological basis of the present work. The analysis of external and internal political, economical and social factors which influence the Russian-Chinese relations in the study period, allows to present an objective scientific picture of the development of bilateral cooperation.

The solution of these problems is based on the algorithm of the system approach, since such a complex and dynamic phenomenon as Russian-Chinese relations, can get an objective assessment only from the standpoint of an integrated consideration of all factors and causes that affect its dynamics, influencing its nature, driving forces etc. The use of system-structural method enabled to reconstruct the mechanism of interaction between the components of relations in the field of culture and education, system elements of interstate relations in the humanitarian sphere.

While making a research the following complex of scientific methods was used: analysis and synthesis, induction and deduction, measurement, description, explanation, generalization, and others. Besides the methods that are widely used in modern historical studies, such as historical and systematic, comparative-historical, retrospective, quantitative analysis and others were also used.

\section{Results}

In the 1990s it became possible to implement large projects of bilateral cultural cooperation such as: annual cultural festivals, a variety of activities in the field of sports, tourism, theatrical and musical arts. The exchange in the field of culture had particularly intensified by the end of the 1990s. It was connected with the preparation for the anniversary of the People's Republic of China.

In 1997 - 1998 the Days of Chinese Culture were held in Moscow, St. Petersburg, Vladimir, Suzdal, Nizhny Novgorod, Novosibirsk, Khabarovsk and the Days of Russian Culture were held in Beijing and Shanghai. Those festivals were held under the patronage of the Ministry of Culture of the two countries. In 1998 during the official visit of the Foreign Minister of the People's Republic of China Tang Jiaxuan in Russia two intergovernmental agreements were signed: on trips by Chinese and Russian citizens in both countries for the purpose of cultural exchange; on mutual abolition of visas for group tourism.

In 1999 Chinese cultural community widely celebrated the 200th anniversary of the birth of A.S. Pushkin, his collections of poetry and prose were reissued, a commemorative series of Complete Works of the great Russian writer and poet was published (Grishin, 2010). In the final event of the Pushkin week the President Jiang Zemin took part.

In 1999 the governments of the two countries celebrated the 50th anniversary of the founding of the PRC and the 50th anniversary of the establishment of the diplomatic relations. In connection with these events a series of celebrations was held. A number of symphony concerts of Russian and Chinese musicians, performances of the Central Ballet Troupe of China, a circus troupe and Song and Dance Ensemble of the miners took place in Russia.

In 2000 the performances of the State Academic Folk Dance Ensemble under the direction of I.Moiseev took place in China. The ensemble was considered the best foreign team in the International Year of folk dance in China. During the celebration of the 55th anniversary of the Victory in the World War II in May 2000 Russian groups represented the program "Songs of the war years" in Beijing, Shenyang and Changchun, Russian artists took part in the International Festival "2000 - meeting in Beijing" (People Daily, 2000).

In December 2000 the Vice Premier of the State Council Li Lanqing visited Russia, during the visit a plan of cultural cooperation between the governments of the Russian Federation and the People's Republic of China for $2000-2002$ and a protocol on cooperation between the Ministries of Culture of Russia and China for 2001 2002 were signed.

The next phase of the Russian-Chinese cultural relations was the signing in June 2001 of the "Agreement on Friendship and Cooperation between the Russian Federation and the People's Republic of China" (Official site of 
the President of the Russian Federation, 2001). The key joint activities, including the ones in the field of culture were implemented as a part of this agreement.

In April 2002 a delegation of the Ministry of Culture of Russia led by M.E. Shvidkoy participated in a meeting of Ministers of Culture of the Shanghai Cooperation Organization (SCO), the result of which was a Joint Statement of Ministers of Culture of the Shanghai Cooperation Organization.

In May 2002 Moscow hosted the second meeting of the Sub-Commission on cooperation in the field of culture of the Russian-Chinese commission on cooperation in the fields of education, culture, health and sports. According to the documents of the Russian Embassy in Beijing in 2002 China was visited by about 65 Russian artistic groups numbering about 1,800 , four major exhibitions were carried out in several cities in China. A variety of activities in the field of culture were included into the Exchange program for 2003-2005 signed by the Ministry of Culture of Russia and China. The central event of the program became the Days of Russian Culture in China in 2003 and the Days of Culture of China in Russia in 2004 (Van Chentsay, 2007).

In April 2005 a delegation of the Ministry of Culture was sent to China for negotiations on the preparation of cultural activities within the organization of the Year of Russia in China in 2006. In October 31, 2005 a regular meeting of the Russian-Chinese commission on cooperation in the field of education, culture, health and sports was held in Beijing. The meeting summed up the work of the Commission during the reporting period, with the main attention paid to the preparation and celebration of the Year of Russia in China in 2006 (Ministry of Culture, 2006).

On the whole the period from 2001 to 2005 was connected with the strengthening of Russian-Chinese relations in the field of culture and preparation of a large-scale project in the humanitarian sphere - the organization of the Year of the Russian Federation in China and the Year of China in Russia in 2006 - 2007 . (Chinese Official Information Center, 2006). The political and cultural significance of these events is confirmed by the personal participation of the Chinese President Hu Jintao and the Russian President Vladimir Putin in the opening ceremony of the "Year of Russia in China" (Ministry of Culture, 2006).

A continuous exchange of visits of the heads of the states, the mechanism of regular meetings between the parliaments and political parties, signing a number of agreements and contracts in the framework of "national years" contributed significantly to the intensification and transition to a qualitatively new level of political and humanitarian cooperation between Russia and China (Larin, 2005).

In 2008 an agreement was reached to transfer the most significant and successful events in the economic, scientific, technological, cultural, sports and other fields on a regular basis. Particular attention was paid to youth contacts. It was planned to hold the Year of the Russian Language in China in2009 and the Year of the Chinese Language in Russia in2010. More than 260 events were conducted in 14 provinces, 4 autonomous regions, 4 municipalities and 26 cities of the People's Republic of China in the Year of the Russian language in China. They were various in nature and included thematic and scientific conferences, seminars and workshops, university and school festivals, competitions and Olympiads on the Russian language and Russian culture, etc. (Year of the Chinese Language in Russia, 2010). These activities have contributed to a significant increase in the interest of the Chinese students to study the Russian language, have enabled the broad masses of the Chinese people to get acquainted with Russia, its culture (Chinese Official Information Center, 2010).

2010 was the Year of the Chinese Language in Russia. Various exhibitions, fairs, festivals, including the Chinese and Russian students, the week of the Chinese movies, Chinese culture, Chinese music, Chinese artists concerts, etc. were held during that year . Russian scientific association of the Chinese language teachers was established, the house of the Chinese language teachers and the Internet Confucius Institute were open.

One of the most successful international projects in the humanitarian sphere in the Year of China in Russia and the Year of the Chinese Language in Russia was the opening of the Russian centers in China and the Confucius Institute in Russia, promoting their culture and language abroad.

According to the Decree of the President of the Russian Federation number 796 of 21 June 2007 a fund "Russian World" was established (the Official site of the "Russian World", 2008). It is an organization implementing a project to establish a network of Russian centers, which are aimed at the preservation and promotion of the Russian language and Russian literature.

In 2009 the fund opened the first three Russian centers in China: on the ground of Dalian University of Foreign Languages (a branch in Port Arthur), in Jilin University (Changchun) and Peking University (Beida, Beijing), in 2010 two more centers were open in Shanghai and Macao universities. In addition an opening of a Russian World Room (similar to the Confucius Classroom) is being planned. 
But this is not a new project of this kind, after the signing of the Treaty of Friendship and Cooperation in June 16, 2001 China has opened three centers for the study of the Russian language: on the ground of Beijing University of the Foreign Languages (China's first and the twentieth in the world) and Shanghai University of the Foreign Languages and Heilongjiang University (Harbin) (People's Daily, 2008).

Fund "Russian World" provides grants to support and study the Russian language in the world. In 2008 - 2009 years. They received a number of Chinese projects: "The program distance learning Russian as a foreign language in China," project "Shanghai art galleries", the publication of Russian-Chinese bilingual magazine. In addition to the opening of the Year of Russian Language Fund has prepared the Chinese specialists in Russian philology gift - portal "Russian World" began to operate in the Chinese language.

China also contributed to the development of Russian-Chinese relations in the sphere of education and culture.

As part of the National Years on the basis of a number of Russian universities were opened Confucius Institutes (孔子 学院, hereinafter - IR) (Official website of Hanban, 2007). On the territory of Russia was originally planned to open only three IR, but at the moment considered the application of two universities in Russia's intention to open the IR to the existing 15 Institutes and Confucius Classroom 2 (Official site Hanban, 2014).

However, at the eighth meeting of the Russian-Chinese subcommittee on cooperation in the field of education (March 2008, China, Beijing) was recorded joint decision to adhere to the principle of equality at the opening of the Confucius Institute in the Russian Federation and the Russian Language Center in China, which in is not currently running ( 5 centers in China and 17 IR in Russian) (Official site of the President of Russia, 2008). Furthermore, in the centers outlined some of the aspects requiring more thorough analysis.

In general, the establishment of such centers contributes to the development of cultural and educational ties between China and Russia, not only at the government level, but also at the level of individual contacts. Such projects can increase the interest of citizens in the culture and history of our countries and expand the study of Russian and Chinese languages. Note that currently some 100 Russian universities teach the Chinese language, 40 of them Chinese language is taught as a first foreign language, and the number of comprehending his undergraduate and graduate students has exceeded 10 thousand.

\section{Discussions}

Russian-Chinese relations are an object of constant study of Russian and foreign scientists. Updating of the international political and economic system makes it possible to take new sources into scientific use, explore historical subjects in a new light, interpret historical processes differently. Under these circumstances, not only Russian historiography, but also overseas one is of great interest for us.

In the 1990s a new stage in the national historiography begins, what was associated with the opening of archives, revaluation of historical facts. There is an opportunity to work directly in the archives and academic institutions of China, so that new important publications on the Russian-Chinese relations appeared, affecting all areas of bilateral relations.

A relatively large number of publications of Russian researchers are devoted to bilateral relations between Russia and China since the 1990s. Activation of interstate relations between Russia and China at the present stage acquired interest not only to the history of Russian-Chinese relations, but also to the problems of cultural cooperation. In addition to monographies and individual studies a number of scientific articles on cultural and educational exchange were published.

The publications of our scientists V.L. Larin (2005), B.V. Bazarov (2002), D.V. Ganzhurova (2002), V.G. Datsyshen (2007) should be especially noted, the sections of which are devoted to the problems of the Russian-Chinese cultural relations at the end of the XX - XXI centuries. V.L. Larin (2005) gives an overall assessment of the cultural and scientific interaction between Russia and China since the late 80s of the XX-th century up to2005, noting both its positive and negative aspects. He points out the difficulty in assessing the effectiveness of cross-cultural and scientific relations, but at the same time mentions that one should not underestimate the possibility of such interaction (Larin, 2005). B.V. Bazaars and D.V. Ganzhur (2002) in their monography consider various aspects of Russian-Chinese relations (1989 - 1999) through the prism of East-Siberian regions. The key point is to identify the role of the bilateral relations in the development of Russian border areas (Bazarov, Ganzhur, 2002). An outstanding sinologist, professor V.G. Datsyshen (2007) examines in his recent works the history of learning of the Chinese Language by Russians, the main centers of Chinese studies, as well as the penetration of Christianity and Orthodox Russian culture into China. The value of this research is to identify the role of Russia, Russian culture and their impact on China, as well as in the study of the history and stages of development of Russian Sinology. 
In China the interest to Russian-Chinese relations at the present stage has increased to the 90 -s XX. Since the end of the 1990s the scientific staff of the institutes and centers of Russian Studies have renewed, the range of aspects of Russian studies have expanded. In 2004 a professor of Beijing Pedagogical University, an expert on Russia Zhang Jianhua (张建华) took the initiative to define 《俄罗斯 学》 (Russian studies) as a separate discipline. It necessary to mention the works of specialists in the history of Sino-Russian relations Binchao Geng (1993), Laosan (1995), Liu Deshi (1996) and others.

By the mid-90s XX after the completion of the first major humanitarian projects such as "The Year of Russia in China" (1997), "The Year of China in Russia" (1998) etc., scientific studies on bilateral relations in the sphere of culture and education since the era of the Qing Dynasty are published in China. These works present the results with different degree of objectivity of researches on issues of humanitarian cooperation between Russia and China and its impact on the political atmosphere between the two countries. The term "cultural diplomacy" plays an important role in the theoretical justification, the term was introduced by an American scientist F. Barghoorn (1954) in the period of "cold war". In his works, Chinese scientists are considering the function of the "cultural diplomacy" and its role in the development of Russian-Chinese relations. It should also be noted that the work of Chinese writers are largely based on the materials introduced into the scientific revolution Russian historians.

Of particular note is the work of European and American historians, which deal with certain aspects of Russian-Chinese relations, as well as a comparative analysis of some features of the historical development of these countries.

The first group of English works - the study of a general nature relating to the history of China and the Russian-Chinese relations in general. First of all it is necessary to mention the 15-volume work of scientists at Cambridge University, "The Cambridge History of China» (Cambridge Univ. Press, 2008), covering the period from Qin and Han dynasties until 1982

The second group - the study, which to some extent addressed the issue of Russian-Chinese relations in the field of culture and education. In the last decade in the West, a number of interesting papers on the impact of Russian literature in the Chinese culture, the Chinese perception of Russian in Harbin in the 1920s., The influence of the Soviet Union to China and the Chinese perception of the Soviet Union (Gamsa, 2008). In 2008 came the work of American scientist E. Kask (2008), which addressed the problem of language policies and problems in the education system.

In general, the study of domestic and foreign historiography of cultural and educational cooperation between Russia and China, we see that the scientists carried out extensive work on this issue, has accumulated considerable theoretical and factual material, revealing the position of the countries in foreign policy, the scope of Sino-Russian humanitarian cooperation also giving the opportunity for further work on the stated theme.

\section{Conclusion}

The review of the key events proposed above allows to present the main results, trends and prospects of Russian-Chinese relations in the field of culture.

The formation and development of mutually beneficial bilateral cultural relations is one of the priority areas of interstate cooperation between Russia and China. This process was facilitated by a constructive climate of bilateral political and diplomatic relations, developing trade and economic ties and traditional mutual interest to the cultural heritage of both countries. Cultural exchange and humanitarian ties between Russia and China developed on the basis of national, interdepartmental, regional and cross-border levels.

An important place in the modern interstate Russian-Chinese relations is taken by cooperation in culture, art, education and tourism. Large-scale cultural events, exchange of delegations and information have formed a mutual constructive perception of people of the two states. The importance of interpenetration and cooperation between the two great national cultures is particularly noticeable.

The citizens of Russia and China have shown willingness to free communication and to partnership. Especially developed Political, social and cultural ties between the regions and peoples of Russia and China underwent special development. Broadening and deepening of various information in the countries form a new base for effective interstate economic, socio-political and socio-cultural cooperation.

Modern Russian-China cultural and humanitarian ties and social contacts are becoming an important factor in ensuring the common interests of the two peoples and contribute greatly to the promotion of peace, security and stability in the region and the world at large. 


\section{Acknowledgments}

The work is performed according to the Russian Government Program of Competitive Growth of Kazan Federal University.

\section{References}

24 events dedicated to the Year of Russia in Heilongjiang Province. (2006). The World. Haerbing, China.

A collection of Russian-Chinese agreements. 1949-1999. (1999). Moscow: Terra-Sport.

Already there are more than 80 CI abroad. (2006). Renmin Ribao, July 7.

Basarov B. V., \& Gangurov D. V. (2002). Russian- Chinese relations and the role of Western-Sibirian regions in their development (1989-1999). Irkutsk,132.

Dacishen, V. G. (2006). The history of studying of the Chinese language in the Russian Empire. Blagoveshensk, 183.

Dacishen, V. G. (2007). Christianity in China: history and the present. Moscow, 240.

Gamsa, M. (2008). The Chinese Translation of Russian Literature. Brill, 430. http://dx.doi.org/10.1163/ej.9789004168442.i-430

Gen, B. C. (1993). Sino-Russian relations in the new international environment. Contempor ary international relations, 1 .

Grishin, Y. Y., \& Zainullin, D. G. (2010). The Chinese fenomenon. Kazan, 112.

Hanban official website. (2014, September 12). Retrieved September 12, 2014, from http://hanban.edu.cn/confuciousinstitutes/node_10961.htm

Kaske, E. (2008). The Politics of Language in Chinese Education. Leiden, Boston, 540.

Larin, V. L. (2005). Russian-Chinese relations on regional scales in the 80-s XX-the beginning of XI. Moscow, 390.

Liu, D. X. (1996). Sino-Russian relations after the collapse of the USSR. Haerbing, China.

Lu, N. Q. (1996). Russian-Chinese relations after the elections in Russia. International Economic Review, 7-8, 23-32.

Ma, F. S. (2009). The study of cultural relations between Russia and China. Social Science, 11, 26-32.

Maslov, A. A. (2009). Russia-China: the stages and problems of educational exchange in XX-XI. Cooperation between Russia and China in the sphere of education: the analysis of the past and perspectives for the future. Moscow, 133-160.

Ministry of Education and Science of the Russian Federation official website. (2013, September 12). Retrieved September 12, 2013, from http://www.russia.edu.ru/news/events/kitai/3709/

National Cultural Development Plan “Eleventh Five” period. (2006). (Национальный план развития культуры в период 11 пятилетки). Renmin Ribao, September 15.

Official site of the "Russian World". (2014, September 12). Retrieved September 12, 2014, from http://www.russkiymir.ru

Official website of the China Internet Information Center. (2014, September 12). Retrieved September 12, 2014, from http://russian.china.org.cn/china/node_7101749.htm/

Official website of the Ministry of Culture. (2014, September 12). Retrieved September 12, 2014, from http://mkrf.ru/

Official website of the President of Russia. (2014, September 12). Retrieved September 12, 2014, from http://www.kremlin.ru

Official website of the Russian Foreign Ministry. Department of Information and Press. (2014, September 12). $\begin{array}{llll}\text { Retrieved } \quad \text { September } & 12, & 2014, & \text { from }\end{array}$ http:/www.mid.ru/nsrasia.nsf/1083b7937ae580ae432569e7004199c2/abcb9cd00fafcaa6c3256e2800413897 ?OpenDocument

Renmin Ribao official website. (2014, April 20). Retrieved April 20, 2014, from http://www.russian.people.com.cn 
The Cambridge History of China. (2008). Vols.9 - 15.: The Ch'ing Empire to 1800, Part 1 - The People's Republic, Part 2: Revolutions Within the Chinese Revolution/ - Cambridge (England) etc: Cambridge Univ. Press.

To promote jointly Confucius Institute to the universities and the community - the main global messege of the member of the State Council and the Chairman of the headquarters of the Confucius Institute Liu Yandun at the Seventh Conference of the Confucius Institute, Beijing, China. (2012).

Wang, C. C. (2007). The Year of China in Russia. China, 13, 56-58.

Year of Chinese Language in Russia official website. (2014, September 12). Retrieved September 12, 2014, from http://www.chinafest.ru/site/svyazi.php

Yi, L. S. (1995). The history of Sino-Soviet relations. Shanghai, 238.

\section{Copyrights}

Copyright for this article is retained by the author(s), with first publication rights granted to the journal.

This is an open-access article distributed under the terms and conditions of the Creative Commons Attribution license (http://creativecommons.org/licenses/by/3.0/). 